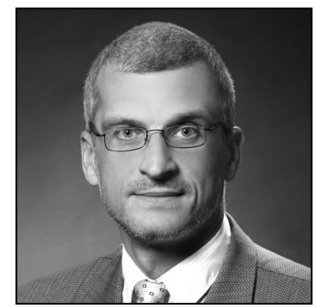

Gaabriel Tavits

Docent of Labour and Social Security Law

University of Tartu

\title{
The Right to Collective Action in Labour Relations in Estonia: Is the Right to Organise a Strike Guaranteed?
}

\section{Introduction}

The right to strike is an integral part of contemporary labour law. This right has been recognised as an important human right and also been considered to be an integral element tied in with the procedure required for concluding a collective agreement. ${ }^{*}$ In the modern information society, however, one might ask whether such an option is necessary or even feasible.

Collective actions in labour relations have suffered their first setback in the European Union with the Laval case, through which the European Court of Justice (ECJ) accorded the freedom of the free movement of services higher priority than the right to organise collective actions in labour relations, both established also by the Charter of Fundamental Rights of the European Union.

In the negotiations in Estonia between shipping company AS Tallink and the Seafarers Union, the public conciliator stated that the strike is an outdated tool for settling labour relations and that it hinders normal economic development. ${ }^{*}$

Concurrently, changes in the workplace and work performance as a whole have to be taken into consideration. As workplaces are going to change rather than disappear and it is not always possible to replace everything with electronic means, the changes in workplaces have to be considered ${ }^{*} 3$ in connection with the phenomenon of collective measures, which were originally intended for the context of the Industrial Revolution, and may not function in the contemporary work environment.

Draft legislation on collective agreements and collective labour disputes now being prepared in Estonia foresees certain regulations for the organisation of collective action, including strikes, support strikes, and

Although it was possible to carry out negotiations before concluding a collective agreement in Soviet times, those negotiations were not considered democratic, since no strikes or lock-outs could be organised.

2 H. Pärn. Streik on iganenud manufaktuuriaegne nähtus ['Strike is an old-fashioned method']. - Päevaleht: Ärileht, 20 January 2014. Available at http://arileht.delfi.ee/news/uudised/henn-parn-streik-on-iganenud-manufaktuuriaegne-nahtus.d?id=67640624 (most recently accessed on 18.5.2014) (in Estonian).

3 J.C. Meister, K. Willyred. 2020. aasta töökoht. HarperCollins 2010 (translation into Estonian of The 2020 Workplace by Publication Hermes 2010). 
lock-outs. ${ }^{*}$ At the same time, Estonian employers hold the view that support strikes are not necessary and do not fully comply with the definition of a strike. ${ }^{*} 5$

In recent years, the employers' organisations on international level have made the statement, that there is no right to strike set forth in the International Labour Organization (ILO) conventions and that, therefore, the Committee of Experts on Application of the ILO Conventions and Recommendations (hereinafter 'CEACR') cannot establish the definition of a strike and its characteristics"6.

All the above-mentioned trends lead us to wonder whether the strike and other collective action have any international legal background and how the national state should react in this situation. Also important is the question of whether the strike or lock-out is necessary as the development of society grows more and more digitalised and when a classical strike-stoppage of the work-no longer qualifies as the most appropriate measure for helping the employees to ensure the hearing of their demands in relation to their employment.

This article considers the following aspects of collective action. Firstly, the question about the right to strike shall be examined. The question is considered of whether on the international level a right to strike exists or not. After general consideration of a right to strike, the situation in the Estonian legal system is analysed. As there is a reform of collective labour relations in progress in Estonia, the article also considers the main question surrounding collective actions in this context in Estonia-the question of the legality of the support strike. Are support strikes allowed, and does the organisation of a support strike necessitate any specific international regulations or should this issue be resolved on national level?

\section{The right to organise collective action as a generally recognised human right}

The right to organise collective action, to stand up for the rights of the employers and employees, has not been regulated in detail by international labour law. Also, that body of law pays more attention to the right of trade unions and employees to organise a strike, while the employer's right to organise a lock-out has been discussed very modestly. ${ }^{*}$

Employees' right to organise collective action is reflected in the Universal Declaration of Human Rights ${ }^{*}$. According to Article 23 (4) of that declaration, everyone has the right to form and to join trade unions for the protection of his interests. As membership in a trade union is often connected with the right to organise collective actions, including the organisation of a strike, we may state that the Universal Declaration of Human Rights has indirectly recognised a right to strike. Concurrently, an employer right to organise a lock-out has not been regulated by the Universal Declaration of Human Rights to any extent whatsoever.

Among documents issued by the United Nations (UN), the Covenant of Economic, Social and Cultural Rights has to be mentioned. According to the provisions of its Article 8 (1), an employee has a right to organise strikes, but the organisation of any strike has to be in compliance with national legislation. ${ }^{*}{ }^{*}$ In principle,

4 Kollektiivlepingu ja kollektiivse töötüli lahendamise seadus (Collective Agreements and Collective Labour Disputes Act), draft. Available at http://www.riigikogu.ee/?op=ems\&page=eelnou\&eid=37dcf358-840a-4258-aa98-c3e9551a9 $48 c \&$ (most recently accessed on 15.5.2014) (in Estonian).

5 Ametiühingud ja tööandjad jätkavad ühise lahenduse otsimist streigiõiguste ja kokkuleppevabaduse teemasl ['Trade unions and employers continue to find solutions for a right to strike and freedom of agreements'], 5 September 2014. Available at http:// www.tooandjad.ee/et/kompetents/uudised/17400-ametiuehingud-ja-toeoeandjad-jaetkavad-uehise-lahenduse-otsimiststreigioiguste-ja-kokkuleppevabaduse-teemal (most recently accessed on 14.5.2014) (in Estonian).

6 See 'The employers' position on the right to strike and the International Labour Organization', a piece available at http:// www.business-swaziland.com/new/images/ioe\%20-\%20right\%20to\%20strike.pdf (most recently accessed on 11.5.2014).

7 J.-M. Servais. The ILO and the freedom to strike, pp. 2-4. Available at http://www.law.utoronto.ca/documents/ conferences2/StrikeSymposiumo9_Servais.pdf (most recently accessed on 14.4.2014); K.N. Gusov, N.L. Ljutov. Mezdunarodnoe trudovoe pravo. Moscow: Prospekt 2013, pp. 221-237; B. Gernigon et al. ILO principles concerning the right to strike. ILO 2000.

8 Universal Declaration of Human Rights, available at http://www.un.org/en/documents/udhr/ (most recently accessed on 12.5.2014), Article 23 (4).

9 International Covenant on Economic, Social and Cultural Rights, available at http://www.ohchr.org/EN/ProfessionalInterest/Pages/CESCR.aspx (most recently accessed on 14.5.2014), Article 8 (1). 
this means that the regulation of the right to organise a strike is allowed but every UN member state has a right to establish conditions and restrictions to be followed in organisation of a strike.

The ILO has not directly stipulated that a right exists for employees and employers to apply collective measures to defend their rights. The Committee on Freedom of Association (hereinafter 'CFA') established by the ILO has stated a set of principles according to which the right to strike has to be guaranteed in all countries, along with principles that have to be followed in the organisation of a strike ${ }^{* 10}$; however, no specified legal basis that could be violated has been accepted on the international level. According to the CFA, the right to organise collective action is closely connected with the right to hold the consultations and negotiations required before entry into a collective agreement. ${ }^{*}{ }^{11}$ In the conventions provided by the ILO, no reference can be observed to collective actions, including a right to strike. ${ }^{*}{ }^{12}$

The ILO has been dealing with the issues of strike for several decades. It has to be admitted that in the two most fundamental conventions on freedom of association (convention 87, about protection of the freedom of association and the right of association ${ }^{*} 3$, and convention 98 , about the right of organisation and collective bargaining ${ }^{*}{ }^{14}$ ) include no definition of the word 'strike' or language referring to a right to strike. For this reason, it may be stated that the situation is rather ambiguous, as the ILO accepts the ideology of industrial action and the practice is based on the explanations of the two main supervisory authorities-of the CFA and the corresponding suggestions and opinions of the CEACR, required to guarantee the adoption of conventions and recommendations-which seem to be based on convention 87 and less on convention 98, where no such word as 'strike' is used. Here, it must be pointed out that both of these institutions deal in recommendations and opinions, because the above-mentioned authorities have no right to interpret the work standards established by the ILO. There is no doubt that the ILO, in co-operation with its supervisory authorities, has a sovereign right to establish the principles for organisation with respect to execution of any right to strike. At the same time, the desire to find a reference to international contracts causes doubtagain, the word 'strike' is not to be found in conventions 87 and 98; nor do these conventions make any provisions regulating the issue. In consequence, the carrying forward of the right to collective action on the basis of the standards established by the ILO or UNO is problematic.

The International Organisation of Employers (IOE) made its view apparent in 2012 that, as there is no right to strike under the ILO conventions, it is not possible for the CEACR to proceed to elaborate from the principles of the strike, let alone create a right to strike. ${ }^{*}{ }^{15}$ The position of the employers that there is no right to strike on international level has created much discussion, but that discussions have shown primarily that a right to strike does, in fact, exist on international level and is part of the right and freedom of association. ${ }^{*}{ }^{*}$

10 See B. Gernigon et al. (Note 7)

11 Ibid., p. 11. See also L. Swepston. Crisis in the ILO supervisory system: Dispute over the right to strike. The International Journal of Comparative Labour Law and Industrial Relations 29 (2013)/2, p. 204.

12 Still the right to strike has been mentioned in ILO Recommendation 92, pertaining to voluntary conciliation and arbitration, from 1951, in paragraph 7. Also, reference to the strike can be observed in Article 1 (d) of convention 105, the Abolition of Forced Labour Convention. On this point, see L. Swepston (ibid.), pp. 203-204. See also C. La Hovary. Showdown at the ILO? A historical perspective on the employers' group's 2012 challenge to the right to strike. Industrial Law Journal 42 (2013)/4, pp. 351-352.

13 ILO convention on freedom of association and protection of the right to organise, from 1948 (Co87), available at http:// www.ilo.org/dyn/normlex/en/f?p=NORMLEXPUB:12100:0::NO::P1210o_ILO_CODE:Co87.

14 ILO convention on the right to organise and collective bargaining, from 1949 (Co98), available at http://www.ilo.org/dyn/ normlex/en/f?p=NORMLEXPUB:12100:0::NO::P12100_ILO_CODE:Co98.

15 See the 'Right to Strike' piece referenced in Note 6.

16 Here, the main aspect of the debate has to do with not the right to strike itself but the organisational level of explaining and elaborating on the right to strike and its principles. Therefore, the question of the adequacy of the ILO supervision system has been widely discussed. See, for example, L. Swepston (Note 11), p 204. See also C. La Hovary (Note 12); P.F. van der Heijden. International right to strike under stress. The Hague Institute for Global Justice. Available at http://www.thehagueinstituteforglobaljustice.org/cp/uploads/downloadsprojecten/International-Right-to-Strike-Under-Stress_1372942440.pdf (most recently accessed on 15.5.2014). 


\section{Europe as regional level}

\subsection{The Council of Europe}

The right to collective action is mentioned in the original European Social Charter ${ }^{* 17}$ and in its amended version. ${ }^{*}{ }^{*}$ So far, the European Social Charter, in whichever of its two forms, has been considered to be the only document in which the right to organise collective action, including strikes, is foreseen. ${ }^{*}{ }^{19}$ In Article 6 (4) of the revised social charter, there is a reference to the right to organise strikes, and, according to the case law of the European Committee of Social Rights, also employers' right to organise lock-outs is referred to. According to the explanation of the European Committee of Social Rights, the employer's right to organise lock-outs has not been acknowledged directly, but at the same time the committee has stated that a comprehensive ban on organisation of lock-outs is in contravention of Article 6 (8) of the above-mentioned charter. ${ }^{{ }_{20}}$ The European Committee of Social Rights has also pointed out that the right to organise strikes is not limited merely to concluding a collective agreement; the right to organise strikes has to be guaranteed in any negotiations between the employees and the employer, for resolution of disputes arising from the employment relations. ${ }^{* 21}$ Therefore, we can state that on the regional level-in the framework of the Council of Europe-the right to collective action is more specifically guaranteed than on the international level as a whole. On the international level (i.e., that of the UN and ILO), we may only derive the right to organise collective action, including a strike, but on the European level the right to organise strikes has been anticipated more specifically in the European Social Charter.

\subsection{The European Union}

On the level of the European Union, the regulation of collective action is somewhat complicated. The European Community (today the European Union) was and has been created as an economic union, and it has to be admitted that the European Union has remained an economic union. Whichever measures are applied by the European Union, they are targeted mainly at ensuring the functioning of the economic union and the development of activities connected with it. Although, over time, a social dimension too has emerged in the activity of the European Union, the dominant aspect is going to remain the economic activity of the European Union (common market, common currency, etc.). The recognition or non-recognition of a right to organise collective action in labour relations may be considered one of the means that ensure a competitive economy. The organisation of strikes is often related to the issue of the extent to which the employees get a fair salary and of what kind of work conditions have to be adopted.

The European Union has recognised the possibility of use of collective actions in labour relations, indirectly. The Amsterdam Treaty is an important landmark, in which there is a direct reference to the European Social Charter and, thereby, to employees' right and option to organise collective actions. ${ }^{* 2}$ Article 28 of the Charter of Fundamental Rights of the European Union ${ }^{* 23}$, adopted in 2000, refers to employees' and employers' right to organise collective action. Although the above-mentioned document was not binding until 1 December $2009^{* 24}$, it marked significant progress in the implementation of social rights. Today, the

17 European Social Charter, 1961, available at http://conventions.coe.int/Treaty/en/Treaties/Html/o35.htm (most recently accessed on 12.2.2014).

18 European Social Charter (revised), 1996. Available at http://conventions.coe.int/Treaty/en/Treaties/Html/163.htm (most recently accessed on 12.2.2014). Estonia has ratified the revised version of the European Social Charter. On certain articles, Estonia has set forth reservations; see the accepted provisions, available at http:/www.coe.int/t/dghl/monitoring/socialcharter/Presentation/ProvisionTableRevMarch2013_en.pdf (most recently accessed on 12.5.2014).

19 See S. Evju. The right to collective action under the European Social Charter. - European Labour Law Journal 2 (2011)/3, pp. 196-224.

20 See the digest of the case law of the European Committee of Social Rights, from 2008. Available at http://www.coe.int/t/ $\mathrm{dghl} /$ monitoring/socialcharter/Digest/DigestIndex_en.asp (most recently accessed on 11.2.2014).

$21 \quad$ See Note 20, pp. 55-58.

22 Treaty of Amsterdam, amending the treaty on European Union, the treaties establishing the European Communities and certain related acts. Available at http://www.eurotreaties.com/amsterdamtreaty.pdf (most recently accessed on 12.5.2015), Article 117.

23 Charter of Fundamental Rights of the European Union, available at http://eur-lex.europa.eu/LexUriServ/LexUriServ.do?u ri=OJ:C:2010:083:0389:0403:en:PDF (most recently accessed on 12.5.2014).

24 See http://ec.europa.eu/justice/fundamental-rights/charter/index_en.htm (most recently accessed on 12.5.2014). 
Charter of Fundamental Rights of the European Union is acknowledged as a part of the primary legislation of the European Union, and a meaning has been assigned to the right of organising collective actions in labour relations. Therefore, on the regional level of Europe, the right to organise collective actions, including strikes and lock-outs, has become an important element in the implementation of social rights. ${ }^{{ }^{2} 5}$

In the realm of securing of social rights and the main fundamental rights of the European Union, a conflict that has not been resolved-and one that probably cannot be resolved at all-was detected some time ago. At this point, we should bring into the discussion four judicial decisions ${ }^{{ }^{2} 26}$ with regard to which the European Court of Justice had to exercise discretionary power to establish whether the collective rights foreseen for employees and guaranteed internationally trumped the fundamental rights of the European Union (economic freedoms). Although the ECJ is convinced that social rights, among them the right to organise collective action, belong among the important social rights, the four main fundamental freedoms of the European Union are deemed more important than the social rights. The above-mentioned Laval case, which caused a large amount of confusion and bewilderment, has significant meaning in this connection. ${ }^{*}{ }^{27}$ The ECJ did not exactly exclude the existence of the right to organise collective actions; in the context of the Laval case, the application of this right would have prejudiced the main rights of the European Union too intensively. As counter-action the European Commission made a proposition according to which there should be certain restrictions established to the organisation of collective actions, with account taken of the freedom of establishment and the freedom of providing services ${ }^{*}{ }^{28}$. In principle, the proposition takes us nowhere and directs the Member States toward extra-judiciary intermediation, which enables prevention of potential strike movements. In conclusion, it may be pointed out that the European Union does not restrict the organisation of strikes or any other collective action within its Member States and leaves solutions to the Member States. For that reason, the European Union does not create any theory pertaining to strikes or other collective action in labour relations. However, the right of applying collective actions in labour relations becomes somewhat restricted when cross-border activity is involved and the action starts to hinder the activity of the European Union within the sphere of two main economic freedoms (the right to the free movement of services and that to the free movement of persons). Accordingly, the right to organise collective actions is recognised in the European Union only insofar as it does not reach beyond the national economy and activity within the realm of labour relations.

The legislature of the European Union does not specify which collective actions may be organised or what kinds of rules must be followed. At this point, the European Union has to look for help in the case law of the European Court of Human Rights (ECtHR) or the explanations of the European Committee of Social Rights. Consequently, the European Union does not deal with the regulation of collective actions and, with high probability, will never start to do so. ${ }^{29}$

25 At this point, it is important to make reference to the fact that, according to Article 153 (5) of the Treaty on the Functioning of the European Union, the EU shall not interfere in activities in the areas of pay, the right of association, the right to strike, and the right to impose lock-outs.

26 The special literature refers to the 'Viking quartet'. These four decisions are ECJ C-438/o5 (Viking), ECJ C-341/o5 (Laval), ECJ C-346/o6 (Rüffert), and ECJ C-391/o5 (Commission v. Luxembourg). See, for example, M. Kielbasa. The fundamental freedoms versus the right to collective action at the EU's internal market. Presented at the Electronic International Interdisciplinary Conference, 2-6 September 2013, available at http://www.eiic.cz/archive/?vid=1\&aid=3\&kid=20201-93\&q=f1 (most recently accessed on 12.2.2014); see also C. La Macchia. The protection of the strike in the internal national legal systems. - P. Edisse. The Right to Strike in the EU: The Complexity of the Norms and Safeguarding Efficacy. 2011, pp. 48-59. Available at http://www.ictur.org/pdf/Right_To_Strike.pdf (most recently accessed on 12.5.2014).

27 See M. Kielbasa (ibid.); N. Reich. Free movement v. social rights in an enlarged union-the Laval and Viking cases before the ECJ. - German Law Journal 2008/9, p. 133. See also C. La Macchia (Note 26).

28 Proposal for a Council regulation on the exercise of the right to take collective action within the context of the freedom of establishment and the freedom to provide services, 21.3.2013 $\operatorname{COM(2012)~} 130$ final.

29 On the relationship between the ECJ and ECtHR, see A. Veldman. The protection of the fundamental right to strike within the context of the European internal market: Implications of the forthcoming accession of the EU to the ECHR. - Utrecht Law Review 9 (2013)/1, available via http://www.utrechtlawreview.org/ ((most recently accessed on 15.5.2014). 


\section{The right of collective action in Estonian legislation}

\subsection{Collective action in industrial relations and the Constitution}

Considering what has been said above, we can conclude that the right to collective actions for employees and employers on international level has been regulated in a modest way. In consequence of such modesty of regulation, the individual countries and their legislation will remain responsible for legal regulation of strikes and lock-outs. ${ }^{*} 30$

In historical terms, the strike as a collective means of dispute settlement has been mentioned in the constitutions of Estonia since the early 1920s. In the Constitution of $1920^{* 31}$ (in §18), it was stated that the freedom to strike is guaranteed in Estonia. In the Constitution of $1938^{*}{ }^{* 2}$, the legal regulation of collective action was modest, with $\S 27$ providing that the settlement of disputes, including the right to strike, would be regulated by law.

With 1992 and the adoption of the current Constitution ${ }^{*} 33$ came another modest expression of the right to strike. Section 29 of the Constitution states that the right to strike is guaranteed. However, the current Constitution of Estonia does not provide further explanation of what this right entails. The Constitution mentions only that the exercise of the right to strike shall be regulated by a separate law. In the Constitution of 1992, the right to strike has been recognised, but its boundaries are not clearly defined. However, the current Constitution does recognise the right to collective action more broadly than as referring to only strikes, and this gives us an opportunity to argue that the employer's right to organise lock-outs too is recognised. ${ }^{*} 34$

In Estonia, the right to apply collective action toward resolution of industrial disputes is regulated in a law about the settlement of collective labour disputes that dates back to $1993 .{ }^{*} 35$ In the time the latter act has been in force, there have been three major strikes ${ }^{*}{ }^{36}$ and weaknesses related to the exercise of the right to strike have emerged. From 1993 onward, in contrast, no lock-outs have been organised, so lock-outs' regulation currently remains only theoretical. There is no case law on lock-outs in Estonia.

In 2009, Estonia succeeded in reforming the entirety of employment law pertaining to individuals. All necessary aspects of individual employment relationships have been codified in the Employment Contracts Act ${ }^{*} 37$. The Ministry of Social Affairs has now prepared a new draft act on collective labour relations. This draft is intended to address the regulation of collective bargaining, conclusion of a collective agreement, and settlement of collective labour disputes ${ }^{*} 38$.

30 This is indicated in the International Covenant on Economic, Social and Cultural Rights, under which the right to strike is guaranteed, and indeed recognised, but this right can be realised in accordance with the rules established in the country. See Article 8 (1) a.

31 Eesti Vabariigi põhiseadus 1920 (Constitution of the Republic of Estonia, 1920). Available at https://www.riigiteataja.ee/ failid/1920.htm (most recently accessed on 14.5.2014) (in Estonian).

32 Eesti Vabariigi põhiseadus 1938 (Constitution of the Republic of Estonia, 1938). Available at http://www.hot.ee/evp1938/ evp.htm (most recently accessed on 14.5.2014) (in Estonian).

33 Eesti Vabariigi põhiseadus 1992, (Constitution of the Republic of Estonia), available at https://www.riigiteataja.ee/akt/633949, English translation available at http://www.legaltext.ee/et/andmebaas/tekst.asp?loc=text\&dok=XooooK2\&keel=en\&pg=1 \&ptyyp=RT\&tyyp $=X \& q u e r y=p \% F 5$ hiseadus (most recently accessed on 15.5.2014).

34 Although the comments accompanying the Constitution do not state that employers have a right to organise lock-outs, the authors of the comments to the Constitution state that employers have a right to use collective action in order to protect their social and economic interests. Põhiseaduse kommenteeritud väljaanne ['Constitution: Comments']. R.-J. Truuväli (ed.). Tallinn: Juura 2012, Section 29, Comment 8.2.

35 Kollektiivse töötüli lahendamise seadus (Collective Labour Disputes Act) - RT I 1993, 26, 442, English version available via http://www.legaltext.ee/ (most recently accessed on 12.2.2014).

36 The 23-29 September 2004 railway strike, July to September 2012 strike of teachers, and 1-26 October 2012 strike of nurses and doctors.

37 Töölepingu seadus (Employment Contracts Act) - RT I 22.12.2012, 30. English version available at http://www.legaltext. ee/et/andmebaas/tekst.asp?loc=text\&dok=XXXXo6oK2\&keel=en\&pg=1\&ptyyp=RT\&tyyp=X\&query=t\%F6\%F6lepingu+se adus (most recently accessed on 12.5.2014).

38 Kollektiivlepingu ja kollektiivse töötüli lahendamise seadus (see Note 4). 


\subsection{Strikes and lock-outs in Estonian law}

In Estonian collective labour law, two types of collective action have been regulated: for employees, the right to strike and, for employers, the right to impose lock-outs. Estonia's current law does not foresee that the parties involved in collective labour relations could organise other forms of collective action. However, it cannot be excluded that under the Public Meetings Act public meetings of various types might be organised also for purposes of discussing social and labour issues. ${ }^{*} 39$ Such meetings can be arranged for both political and non-political purposes.

Estonian legislation does not provide detailed regulations addressing organisation of lock-outs. For organising a lock-out, the law foresees employment of the same procedure and principles used in the organisation of strikes. The only differences are connected with the notions specific to the lock-out, the lock-out being an interruption of work upon the initiative of an employer that it initiated to achieve concessions from employees to lawful demands in respect of labour matters. ${ }^{*} 40$ In order to understand requirements related to organisation of lock-outs, one must, therefore, know what the requirements are for organisation of a strike to be legal.

The most important-and, in Estonia, the most often used collective action-is still the strike. A strike can be organised by either trade unions or employees' trustees. According to the Employees' Trustee Act ${ }^{*} 41$, if an employee trustee has been elected in the relevant company, that trustee shall perform all of the tasks associated with employee representation. Also, the trustee has to lead any collective bargaining on the employee side. Among other tasks, the employees' trustee exercises a right to call for a strike. If the company also has a trade union, there is a clear division of tasks: the trade union can negotiate a new collective agreement, and thereby the right to organise strikes is guaranteed. In this case, the employees' trustee does not have competence to conclude a collective agreement or to call for a strike.

Estonian legislation recognises three types of strike: a normal strike, a warning strike, and support of a strike. Of these three possibilities, the normal strike is the least complicated. According to the current definition, a strike is an interruption of work where the aim is to achieve concessions from an employer to lawful demands in relation to labour matters. ${ }^{*} 42$ In order for a strike to be organised legally, the compulsory conciliation procedures must have been completed first. If the conciliation procedure fails and agreement for settlement of the disputes cannot be reached, it is possible to organise a strike. If a strike is to be organised, notification must be given publicly at least 14 days in advance of the date on which it is due to begin. ${ }^{*} 43$ In cases wherein a strike is organised, to what extent services should be guaranteed during the strike and which services these might be are not clear. According to the principles elaborated upon by the ILO, the minimal level needed for provision of necessary services shall be ensured and, therefore, the right to strike can be limited in certain sectors of the economy. ${ }^{*} 44$ At present in Estonia, there is no list of services that should be guaranteed. In practice, however, the trade unions that have called for a strike have ensured that the operation of certain services continues. ${ }^{*} 45$

With respect to exercise of the right to strike, the situation is the most complicated for warning strikes and support strikes. For organisation of a warning strike, Estonian legislation does not foresee any specific requirements. The only requirement the law specifies is the obligation to inform the public about any organisation of a warning strike. Notice has to be given three days in advance. ${ }^{*}{ }^{6} \mathrm{~A}$ warning strike does not require any previous conciliation procedures. Warning strikes can be carried out while the negotiation procedure is

39 Still we cannot view such public meetings as collective action under the right and freedom of association. See Avaliku koosoleku seadus (Public Meeting Act) - RT I 1997, 30, 472, English version available at http://www.legaltext.ee/et/andmebaas/ tekst.asp?loc $=$ text\&dok=2013X16\&keel=en\&pg $=1 \& p t y y p=R T \&$ tyyp $=X \& q u e r y=$ avaliku+koosoleku+seadus (most recently accessed on 12.5.2014).

40 See Kollektiivse töötüli lahendamise seadus (Note 35), §2 (3).

41 Töötajate usaldusisiku seadus - RT I 2007, 2, 6 (Employees' Trustee Act). English version available at http://www.legaltext. ee/et/andmebaas/tekst.asp?loc=text\&dok=XX10005K2\&keel=en\&pg=1\&ptyyp=RT\&tyyp=X\&query=usaldusisik (most recently accessed on 12.5.2014).

42 See Kollektiivse töötüli lahendamise seadus (Note 35), §2 (2).

$43 \quad$ Ibid., $§ \S 13$ and 15.

44 See B. Gernigon et al. (Note 7), pp. 20-23.

45 See, for example, news pieces on the strike of doctors in Estonia in 2012, such as Arstide streik algas ['The strike of doctors has started'], available at http://uudised.err.ee/v/eesti/04a5e623-3023-465a-9457-4ebe8b453ab4 (most recently accessed on 14.5.2014) (in Estonian).

46 Kollektiivse töötüli lahendamise seadus (see Note 35), §18 (2). 
in progress. A warning strike can be considered an important component of collective bargaining by which means employees can exert pressure on the employer toward the goal of meeting of their demands.

The most problematic type of strike in Estonia is and will remain the support strike. The main argument here is associated with the nature of a support strike. This type of strike does not correspond to the concept and definition of a strike as set forth by the legislator. According to the Collective Labour Dispute Resolution Act, a strike is an interruption of work on the initiative of employees or of a union or federation of employees that is undertaken for gaining of concessions from an employer or an association or federation of employers to lawful demands on labour-related matters (see §2). The support strike does not correspond to that aim. The idea of a support strike is to perform an act of solidarity with the employees involved in the main strike. Therefore, the support strike should be viewed not as a type of strike but as a solidarity action that might be equivalent to, for example, a public meeting. ${ }^{*} 4$

The support strike is a crucial type of action in two respects: 1) it can be organised regardless of whether the employer has concluded a collective agreement with its employees or not and 2) an employer of those by whom a support strike is organised cannot do anything in order to prevent the action. This is the situation seen in Estonia. Even if an employer has concluded a collective agreement, that employer still has to take into account that there might be some unexpected interruptions in its day-to-day business due to support strikes. Although this set of circumstances might be in accordance with international standards, one may still ask whether it is reasonable.

Taking into account what has been said above, one might readily question whether there is still a need for the support strike. There is no specific rule on international level for organising support strikes. Although both the ILO and the European Committee of Social Rights recognise the right to arrange a support strike, there are several countries where the support strike is not recognised as legitimate. ${ }^{*} 48$ Also lacking are statements of solid logic for recognising and regulating support strikes. The aid of a support strike does not make it possible to resolve any problems that have been raised during the main strike. Also, the support strike cannot be viewed as an integral element of the right of association, as this action does not express the relevant trade union's activity to achieve for its members better employment and other social conditions.

Problems arise also in connection with the economic side of a strike. A situation may arise wherein the employer involved in the main strike still has an opportunity to continue its economic activity, at least at minimal level. At the same time, an employer by whose employees a support strike is organised may not be able to continue its activity and could suffer considerable economic and other losses. Accordingly, a right to carry out a support strike could be harmful for both employees and employers: the employers must always take into account possible losses in their economic activity, and their employees cannot bring themselves better employment conditions via the support strike.

One might ask how the concept of the support strike is connected with the generally recognised right to strike. As is noted above, the International Organisation of Employers has already pointed out, in 2012, that on the international level (in ILO conventions and recommendations) there is no direct right to strike codified. The employers also pointed out that the standpoint of the ILO CEACR with respect to the legitimacy of political and solidarity strikes can also be called into question. ${ }^{*} 49$ The IOE's perspective might be correct, because there is not really any direct or even indirect norm pertaining to a right or even possibility of organising support strikes.

At the same time, the situation at European regional level is different. Within the framework of the Council of Europe, it has been recognised that there is a fundamental right to organise solidarity strikes and that it shall be governed by the European Convention on Human Rights (ECHR), Article 11. In the recent case $R M T v . U K^{*}{ }^{\circ}$, the ECtHR had to decide about the legal status of solidarity strikes. The Court decided

47 The ILO CFA does not say very clearly that there is a right to organise a support strike. It has only mentioned that general prohibition of a support strike could lead to abuse and that the initial strike they are supporting is itself lawful. See, for example, B. Gernigon et al. (Note 7), pp. 15-16.

48 See W. Warnek. Strike rules in the EU27 and beyond: A comparative overview. Brussels: ETUI 2007. Available at http:// www.etui.org/Publications2/Reports/Strike-rules-in-the-EU27-and-beyond (most recently accessed on 14.5.2014).

49 See the piece 'Why the crisis in the ILO Standards Supervisory System matters to governments', available at http://www. ioe-emp.org/fileadmin/ioe_documents/publications/Policy\%20Areas/international_labour_standards/EN/_2013-11-18_ Why_the_Crisis_in_the_ILO_Standards_Supervisory_System_matters_to_Governments__web_.pdf (most recently accessed on 19.5.2014).

50 The case of the National Union of Rail, Maritime and Transport Workers v. the United Kingdom, application 31045/10, 8.4.2014. See also L. Lavrysen. Strasbourg Court fails to adequately protect trade union freedom: Secondary strike action only 
firstly that the right to take secondary actions-i.e., to organise solidarity strikes-is, in fact, governed by Article 11 of the ECHR, as stated above. This means that solidarity actions encompass the right to organise solidarity strikes and that these, therefore, are a part of trade union activity as covered by Article 11. The Court also refers to the ILO CAF here and to the CEACR. ${ }^{*}{ }^{51}$ The ECtHR held also that if in one country there exists a restriction on organising of solidarity strikes, this ban does not constitute a violation of Article 11 of the ECHR. ${ }^{*}{ }^{2}$ The decision means that restrictions on organisation of support strikes do not necessarily constitute any violation of fundamental freedoms and rights. The decision offers an opportunity to think about whether the support strike is still a necessary means for protecting employees' rights.

In general, one can say that the right to strike exists and that it is not possible to avoid the existence of this right. At the same time, it is necessary to ask whether a support strike should, perhaps, not be viewed as a strike at all and whether such activity should still be viewed as an integral element under collective labour law that is to be protected even on international level. The purpose and aim of the support strike can be realised via other means. For instance, in Estonia under the Public Meetings Act, the support strike could be deemed to be a specific type of public meeting. One could say that the support strike as a type of strike is out of date. The question we should still pose is of whether the support strike actually is in keeping with the notion of the strike as such.

If we accept the idea of the support strike as valid, the same right should exist on the employer's side, to balance the parties' power: the right to organise a support lock-out. So far, there has been no discussion in the literature about warning lock-outs or support lock-outs.

\section{Specific forms of organisation of a strike}

The developing information society and the digital world must be seen as an important factor affecting the organisation of strikes. What opportunities are currently available for organising a strike, and to what kinds of changes has the modern digital society led us? Typically, when one is organising a strike, one can expect employees to raise their demands against the employer, and usually the organisation of the strike will be supported by other actions, such as public meetings or pickets. Today, action could take place as well in a form we might call a cyberstrike. ${ }^{*} 53$ The cyberstrike might involve attacks on the employer's databases, locking out of data systems, congestion of traffic related to the employer's Web site, or even infection of the employer's various information and other channels with viruses. The notion of the cyberstrike raises the question of how far employees may legitimately go in order to disturb the activity of the employer. In this connection, the inevitable question already discussed above also arises: what about the validity of the support strike, in whatever form? Although the ILO's Freedom of Association Committee and the European Committee of Social Rights allow organising of support strikes on the condition that the main strike is legal, a question remains as to the ways in which a support strike can take place-can a support strike take place legitimately as work stoppages or not, or can it consist, for example, of blocking of access in different ways ${ }^{*} 54$ to an employer's database for a certain period of time? Consequently, the question may arise also of what conditions must be imposed on the support strike, especially in forms such as a support cyber strike. Estonian law does not place any conditions on the right to carry out a support strike. Accordingly, for example, if railway workers were to organise a strike that is meant for bringing about greater occupational

considered to be an 'accessory' aspect of Article 11 (R.M.T. v. UK), available at http://strasbourgobservers.com/2014/05/12/ strasbourg-court-fails-to-adequately-protect-trade-union-freedom-secondary-strike-action-only-considered-to-be-anaccessory-aspect-of-article-11-r-m-t-v-uk/ (most recently accessed on 18.5.2014).

$51 \quad$ See M. Kielbasa (Note 26), pp. 30-32.

52 There are only a few states in Europe where secondary actions, including sympathy strikes, are forbidden. These countries are the United Kingdom, Austria, Luxembourg, the Netherlands, and Latvia. Usually, secondary actions are associated with certain restrictions. See W. Warnek (Note 48).

53 In the framework of cyberstrike it might be worth differentiating various types of actions and the legal ramifications. For instance, individual employees loading the company's Web pages a few times a day and cumulatively creating denial of service might be of a different order than defacing the homepage. Also, the use of the term 'strike' for this brings in several questions that need further legal analyses, just as one might question whether it would be more like strike and riot if employees were to break their work machines and smash the factory's windows.

54 For example from changing a server timeout in the office to keeping the server busy with theoretically legit requests from the outside world. 
safety and better wage conditions for them, any other trade union can organise a support strike-for example, workers in the IT sector. A situation could arise in which, for instance, employers during the support strike face shutdowns of their communication infrastructure and information activities. Another question arises here: how far can employees go legitimately before being deemed to violate rules about data protection? As one can see, the scenario of the cyber strike can bring questions into focus that have been only in the background before.

\section{Conclusions}

Employees' and employers' right to organise collective action is recognised both internationally and at the European regional level. In documents adopted by the UN and the ILO, there is no specific rule on the existence of a right to strike, nor is one referred to, but various interpretations of the rules that are stated recognise a right to employ the strike and the lock-out. At European level, the right to collective action with respect to, inter alia, the right to strike can be found in the European Social Charter and the Charter of Fundamental Rights of the European Union. Because the international level and the European level show no clear guidance on the organisation of strikes, the right to strike and to collective action lie primarily within the field of responsibility of national legislation.

In Estonia, the right to strike has been settled through the Collective Labour Disputes Act. The main problems in Estonia are related to the warning strike and support strike. With respect to organisation of a warning strike, there is no concrete requirement set forth in the legislation as to time and conditions, when and how the warning strike can be organised. Support strikes, on the other hand, are more complex. They do not fulfil the function of a strike or truly match the concept, because the action is not directed against the employer being taken issue with and the intent is not to gain concessions from the employer of those organising the action in question.

Though bearing the name, the support strike does not satisfy the criteria for being a strike and, therefore, cannot be legitimately considered one. The recent case law of the ECtHR has shown that restrictions to guarantees to the right to carry out a support strike are allowed and are in accordance with the ECHR. The time has come to consider whether the support strike is still necessary. 